\title{
CT chest - A rapid screening tool in COVID-19 pandemic
}

Sir,

The COVID-19 pandemic has affected a significant proportion of the population worldwide. Symptoms and signs of chest infections are commonly reported; however, RT PCR is the primary diagnostic modality. In this context, we wish to report on some results from an advanced tertiary imaging centre in south India on the use of CT imaging of the chest in COVID suspected patients. From March 2020 to August 2020, Screening CT Chest was done for all patients undergoing elective surgeries, who were asymptomatic for Viral infection, people exposed to COVID positive patients before one week and all patients who had mild symptoms like cough, body ache, anosmia, loss of taste, mild fever $\left(<100^{\circ} \mathrm{F}\right)$, who didn't require admission. All these patients underwent HRCT and noncontract Spiral CT in the same sitting and the findings of Ground glass opacities, Septal thickening, crazy paving pattern and patchy consolidations or mixed patterns ${ }^{[1]}$ were considered positive by CORADS. ${ }^{[2]}$ The study included all CT screen positive patients who underwent RTPCR for COVID and the results were analysed. Chest CT images were evaluated by two radiologists on both mediastinal (width $350 \mathrm{HU}$, level $40 \mathrm{HU}$ ) and lung (width $1500 \mathrm{HU}$, level -500 HU) window settings defining the pulmonary lesions according to their location, density, shape, and margin.

Six hundred and seventy-four (17.01\%) out of the total 2940 cases with positive CT were asymptomatic, from March 2020 to August 2020 [Table 1]. This included 513 cases with mild CT changes and 161 cases with moderate CT changes. Three hundred and eighty (56.38\%) of the 674 asymptomatic cases did not undergo RT PCR. Only 152 (51.7\%) of the remaining 294 asymptomatic CT positive cases had a RT PCR positive test result after CT chest positivity [Table 2]. Patients who had CT Positive findings but initial RT PCR negative were followed up with repeat RT-PCR testing (with time interval $>4$ days for two consecutive assays), the mean interval between initial negative to positive RT-PCR results was 5.1 days \pm 1 , with a range of 4-7 days and a median of 4 days, which was picked up in 73 patients [Table 3].

According to current diagnostic criteria, viral nucleic acid tests by means of RT-PCR assay play a vital role in determining hospitalization and isolation for individual patients. However, its lack of sensitivity, insufficient stability, and relatively long processing time were detrimental to the control of the disease epidemic. Considering the rapidly
Table 1: Asymptomatic cases patients with identifiable lung involvement in HRCT $(n=2940)$

\begin{tabular}{lc}
\hline Patient status & CT Positive \\
\hline Asymptomatic & $674(22.9 \%)$ \\
Symptomatic & $2266(77.1 \%)$ \\
\hline
\end{tabular}

Table 2: CT Positive Asymptomatic cases ( $n=674)$

\begin{tabular}{lc}
\hline RTPCR Positive & $152(22.5 \%)$ \\
RT PCR Negative & $142(21.06 \%)$ \\
Patients who refused RTPCR & $380(56.38 \%)$ \\
\hline
\end{tabular}

Table 3: Repeat RTPCR in CT Positive Asymptomatic cases ( $n=142$ ), with time interval $>4$ days for two consecutive assays), the mean interval between initial negative to positive RT-PCR results was 5.1 days \pm 1 , with a range of 4-7 days and a median of 4 days

Repeat RTPCR Positive $73(51.5 \%)$

Repeat RTPCR Negative $69(48.5 \%)$

spreading epidemic of COVID-19, the priority was to identify any CT case suspicious for COVID-19. CT features of viral pneumonia should be regarded as strongly suspicious for COVID-19 pneumonia, despite negative RT-PCR test results. The review of the cohort has highlighted typical CT findings that may assist in the early detection of cases and help isolate, treat \& prevent complications. Chest CT has high sensitivity for the diagnosis of COVID-19. Our data and analysis suggest that chest CT should be considered for COVID-19 screening, comprehensive evaluation, isolate these subsets, so we could prevent the spread of the disease in the community and follow-up, especially in epidemic areas with high pretest probability for disease.

Financial support and sponsorship

Nil.

\section{Conflicts of interest}

There are no conflicts of interest.

Bavaharan Rajalingam Magnum Imaging and Diagnostics, Trichy, Tamil Nadu, India. E-mail: bavaharan@gmail.com

\section{References}

1. Simpson S, Kay FU, Abbara S, Bhalla S, Chung JH, Chuing M, et al. Radiological Society of North America Expert Consensus Statement on reporting Chest CT findings related to COVID-19. Endorsed 
by the Society of Thoracic Radiology, the American College of Radiology, and RSNA. Radiol Cardiothoracic Imaging 2020;2. doi: 10.1148/ryct.2020200152.

2. Prokop M, van Everdingen $\mathrm{W}$, van Rees Vellinga $\mathrm{T}$, Quarles van Ufford J, Stöger L, Beenen L, et al. CO-RADS - A categorical CT-assessment scheme for patients with suspected COVID-19: Definition and evaluation. Radiology 2020;296:E97-104.

This is an open access journal, and articles are distributed under the terms of the Creative Commons Attribution-NonCommercial-ShareAlike 4.0 License, which allows others to remix, tweak, and build upon the work non-commercially, as long as appropriate credit is given and the new creations are licensed under the identical terms.

\begin{tabular}{|l|l|}
\hline \multicolumn{2}{|c|}{ Access this article online } \\
\hline Quick Response Code: & \\
\hline & Website: \\
\hline & www.ijri.org \\
\cline { 2 - 3 } & DOI: \\
\hline
\end{tabular}

Cite this article as: Rajalingam B. CT chest $-\mathrm{A}$ rapid screening tool in COVID-19 pandemic. Indian J Radiol Imaging 2021;31:S212-3.

Received: 19-Dec-2020

Revised: 24-Dec-2020

Accepted: 24-Dec-2020

Published: 23-Jan-2021

(c) 2021 Indian Journal of Radiology and Imaging | Published by Wolters Kluwer - Medknow 